\title{
FAKTOR-FAKTOR YANG MEMPENGARUHI TATA KELOLA SDM PEMERINTAHAN
}

\author{
Zulfan Nahruddin 1 \\ Universitas Muhammadiyah Makassar ${ }^{1}$
}

Pengelolaan SDM merupakan bagian penting dalam mewujudkan organisasi yang bergerak pada arah visi, misi, dan tujuan organisasi. Sumber Daya Manusia yang dikelola dengan baik menjadi rangkaian penentu efektivitas organisasi tersebut mencapai visi, misi, serta tujuan yang direncanakan.

Kemajuan organisasi berhubungan dengan kebutuhan akan dukungan kapasitas SDM sehingga perlu proses yang perencanaan melalui rangkaian analisa yang berpatokan pada regulasi sebagai pedoman dan rujukan dalam pengelolaan SDM. Usaha peningkatan kualitas SDM ditempuh melalui upaya yang sinergis antara berbagai pihak dan juga memfasilitasi pelatihan dan pendidikan yang memadai (Wuryandani, 2014). Selain itu kinerja dan manajemen SDM aparatur perlu mendapat pembenahan secara komprehensif yang berbasis pada kompetensi (Ashari, 2010).

Secara umum upaya pengelolaan SDM pemerintahan melalui sejumlah tahapantahapan yaitu perencanaan, pengorganisasian, pelaksanaan, dan evaluasi (Zaenuri, 2015). Sejumlah tahapan tersebut dipengaruhi berbagai faktor dalam proses tata kelola SDM. Adapun faktor yang mempengaruhi tata kelola SDM pemerintahan dapat dikategorikan menjadi dua faktor yaitu faktor internal dan faktor eksternal. Faktor internal terdiri dari misi dan tujuan organisasi, Strategi pencapaian tujuan, dan jenis teknologi yang digunakan sedangkan faktor eksternal yaitu kebijaksanaan pemerintah, sosial budaya, perkembangan ilmu pengetahuan dan teknologi (Handoko, 2005).

Uraian faktor-faktor yang mempengaruhi tata kelola SDM pemerintahan dapat menjadi rujukan gagasan atau ide yang dapat dikembangkan dalam bentuk karya ilmiah antara lain : (1) Strategi Pengelolaan SDM dalam meningkatkan kompetensi ASN; (2) Optimalisasi website atau portal dalam meningkatkan pelayanan publik; (3) Evaluasi Kebijakan Rekruitmen Aparatur Sipil Negara; (4) Budaya Organisasi yang berkembang pada instansi Pelayanan Publik; (5) Penguasaan Informasi dan Teknologi ASN. 


\section{DAFTAR PUSTAKA}

Ashari, E. T. (2010). Reformasi Pengelolaan SDM Aparatur, Prasyarat Tata Kelola Birokrasi Yang Baik. Jurnal Borneo Administrator, 6(2).

Handoko, T. H. (2005). Manajemen Personalia dan Sumber Daya Manusia. Yogyakarta: B.P.F.E. UGM.

Wuryandani, D. (2014). Peluang Dan Tantangan SDM Indonesia Menyongsong Era Masyarakat Ekonomi Asean. Info Singkat Ekonomi dan Kebijakan Publik. Vol. VI, (17), 13-16.

Zaenuri, M. (2015). Manajemen Sumber Daya Manusia di Pemerintahan. Yogyakarta: LP3M UMY. 